\title{
The most common conditions in children that require haemodialysis
}

\author{
VERICA MIŠANOVIĆ ${ }^{1}$, FEDŽAT JONUZI ${ }^{1}$, MIRZA HALIMIĆ' ${ }^{1}$ ASMIR JONUZI ${ }^{2}$, JOVANA PANIĆ ${ }^{1}$, SAMRA RAHMANOVIĆ ${ }^{1}$, SELMA DIZDAR \\ ${ }^{1}$ Paediatric Clinic, Clinical Centre of the University of Sarajevo, Patriotske lige 83, 71000 Sarajevo, Bosnia and Herzegovina \\ ${ }^{2}$ Paediatric Surgery Clinic, Clinical Centre of the University of Sarajevo, Bolnička 25, 71000 Sarajevo, Bosnia and Herzegovina
}

Corresponding author:

Verica Mišanović, $M D, P h D$

Paediatric Clinic

Clinical Centre of University in Sarajevo

Patriotske lige 81, 71000 Sarajevo

Bosnia and Herzegovina

E-mail: averica41@hotmail.com

\section{ABSTRACT}

Haemodialysis is a fast and efficient method for removing toxins from the body in a straightforward manner. This has been a regular practice at the Paediatric Clinic in Sarajevo, Department of Paediatric Intensive Therapy since January 2009. By December 2014 there were 34 patients treated by haemodialysis, who had undergone 253 haemodialyses in total. There were $18(52.9 \%)$ primary nephrologic patients, while $16(41.05 \%)$ were patients whose renal failure was caused by other etiology. The main objective of this paper is to present the most common conditions in childhood that require haemodialysis in its treatment. The Department of Paediatric Intensive Therapy for this period had hospitalized 1,226 patients in total. Out of this number $2.77 \%$ of patients required the application of haemodialysis in their treatment.

The results show that the most common renal causes to perform haemodialysis are: haemolytic uremic syndrome (HUS), chronic renal failure, nephrotic syndrome and congenital bilateral nephrolithiasis. For the others, the most common nonrenal causes are multiple organ dysfunction syndrome (MODS) that occurs as a result of cardiac insufficiency, hepatic insufficiency or after surgeries, as well as in hemato-oncologic diseases.

Key words: child, haemodialysis

\section{INTRODUCTION}

Haemodialysis is a fast and efficient method for removing toxins from the body in a straightforward manner. It is performed extracorporally using dialyzers containing an artificial semi-permeable membrane that is usually made of cuprophane or cellulose acetate. It requires safe vascular access (central venous line) so that the process of dialysis can be repeated safely and multiple times. $(1,2)$

Additional difficulties are the need of anticoagulant therapy (general heparinization), as well as the proportionally quick and extensive displacement of water and dissolved particles that can easily lead to hemodynamic stress and disequilibrium. The main indications for haemodialysis are acute and chronic renal failure, and intoxication with dialyzable toxins (barbiturates, salicylates, methanol). (3)

It is also used in congestive heart failure, severe hypernatremia, metabolic acidosis (especially aminoacidemia in newborns), hepatic insufficiency, hypercalcemia, and primary hyperoxaluria. (4)

Our aim is to present our experiences in treating the most common conditions in childhood that require haemodialysis in their treatment.

Material and methods. The Department of Paediatric Intensive Therapy, Paediatric Clinic of the Clinical Centre of the University of Sarajevo, hospitalized 1,226 patients in the period from January 2009 till December 2014. Out of this number, 34 patients $(2.77 \%)$ required the application of haemodialysis in the therapeutic treatment, and 253 haemodialyses were performed in total.

\section{RESULTS}

Kidney disease as a primary reason for conducting haemodialysis was diagnosed in 18 patients (52.9\%); mostly due to acute renal failure that had occurred as a result of haemolytic uremic syndrome (10 patients or $55.55 \%)$.

The second most common cause was chronic renal failure that occurred as a result of late detected congenital anomalies in the urogenital tract (vesicoureteral reflux, etc.), which was observed in five patients $(27.77 \%)$. In two patients the cause was congenital nephrotic syndrome and in one patient it was bilateral nephrolithiasis resulting from abnormal calcium metabolism.

Other diseases that required haemodialysis in their treatment, but were not a consequence of primary renal impairment, were recorded in 16 patients $(41.05 \%)$.

In hematooncological patients, two patients developed sudden liver failure as a result of hepatotoxic effects of cytotoxic therapy (methotrexate), while in two patients, after inserting the haemodialysis catheter aphaeresis on a cell separator with continuous flowhaemodialysis was performed due to the collection of stem cells for bone marrow transplantation.

Five patients developed multiple organ failure after various surgeries (correction of congenital heart defects, appendectomy, polytrauma, etc.) and in these patients the treatment required the use of haemodialysis.

Out of the remaining seven patients, two patients developed hardened heart failure as the clinical presentation of acute viral myocarditis, four patients developed disseminated intravascular coagulation as the 
clinical presentation of systemic infection - sepsis and SIRS, while one patient developed neonatal metabolic disorder due to hyperammoniemia.

According to the gender structure, 16 of the patients involved were male and 18 female. There were 9 patients in the age group 0-1 year, 10 in the 1-6 years group and 15 in the $7-18$ years group.

The outcome recorded in our patients was: 8 cured, 15 recovered, and 11 deaths.

\section{DISCUSSION}

At the Department of Paediatric Intensive Therapy, Paediatric Clinic of the Clinical Centre of the University of Sarajevo, patients with life-threatening conditions whose treatment requires haemodialysis account for about $3 \%$ of overall hospitalized patients.

The leading cause of acute renal failure is haemolytic uremic syndrome, which in its clinical presentation is dominated by microangiopathic hemolytic anemia, ac- companied by renal dysfunction and hemorrhagic diathesis with thrombocytopenia. Kidney failure is manifested by oliguria, anuria, hyperkalemia and azotemia, which among others also requires the application of haemodialysis in treatment. $(5,6)$

Congenital nephrotic syndrome includes diffuse sclerosis of mesangia (which is a rare disease and the mechanism of inheritance is unknown) and the Finnish type of nephrotic syndrome (an autosomal recessive disorder caused by mutations in gene NPHS1). (7)

Chronic kidney disease is one of the most serious chronic diseases in children. Its prevalence in the population aged from 0 to 18 years is $50-80$ children per million. It is estimated that the incidence of progressive renal disease leading to a terminal (final) stage of renal failure is 6-8 children per million, per year in the population under 18 years of age. The most common reasons for children to need renal replacement therapy are congenital anomalies of the urinary tract and the kidneys. $(8,9)$ Other diseases that require dialysis as an integral part of their treatment are the life-threatening diseases of different organ systems (cardiovascular, hematopoietic, immune, etc.) - often with fatal outcomes due to the development of multiple organ dysfunction, thus requiring a multidisciplinary therapeutic approach. (10)

\section{CONCLUSION}

From the analyzed data it can be concluded that about $3 \%$ of patients hospitalized in the Intensive Therapy Unit for the treatment of the underlying diseases require haemodialysis implementation. The most common causes of renal failure are hemolytic-uremic syndrome and chronic renal insufficiency due to congenital anomalies of urogenital tract. Despite the applied measures of treatment, death occurred in $32.35 \%$ of patients that required haemodialysis, and only partial recovery in almost half of the remaining patients was observed.

\section{REFERENCES}

1. Batinić D. Bolesti bubrega i mokraćnih organa E: Ljiljana Zergollern \& suradnici, Pedijatrija 2.Knjiga, Naprijed Zagreb, 1994 , str.1290-1293.

2. Verica Misanovic, Fedzat Jonuzi, Dusko Anic, Mirza Halimic, Samra Rahmanovic. Central Venous Catheter as Vascular Approach for Hemodialysis - Our Experiences. Mater Sociomed. 2015 Apr; 27(2): 4-9

3. Drukker W, Parsons FM, Mahner JF (eds). Replacment of Renal Function by Dialysis, ed. 2., Martinus Nijhoff. The Hague, 1983.

4. Zobel G, Ring E, Zobel V. Continous arteriovenous renal replacment systems for critically ill children. Pediatr Nephrol 3:140-143, 1989.

5. Gojko Vlatković, Bolesti moraćnih organa kod djece III dopunjeno izdanje, Školska knjiga - Zagreb, 1989 , srt.272-275.

6. Kaplan BS, Remmuzzi C: The haemolytic uremic syndrome. E: Remuzzi G, Rossi EC (eds.): Haemostasis and the Kidney, Butterworths, London, 1989, str.201-236.

7. Mahan JD, Vernier RL: CAONGENITAL Nephrotic Syndrome. U: Hollidday MA, Barratt TM, Vernier RL (eds.): Pediatric Nephrol, ed. 2, Williams\& Wilkins, Baltimor, 1987, str. 457-461.

8. Cvitković Roić A., Roić G., Valent Morić B., Palčić I. : Vezikoureteralni refluks i poremećaji funkcije donjeg mokraćnog sustava, Paediatr Croat. 2014;58:47-50.

9. Roić G., Cvitković Roić A., Grmoja T., Posarić V., Marijanović J., Miletić D., Palčić I.: Slikovne dijagnostičke metode u dijagnostici vezikoureteralnog refluksa: od početaka do danas, Paediatr Croat. 2014;58:51-8.

10. I. Škarić. Treatment of children with complications of cancer therapy and multiple organ failure. Paediatr Croat. 2009;53:255-7 